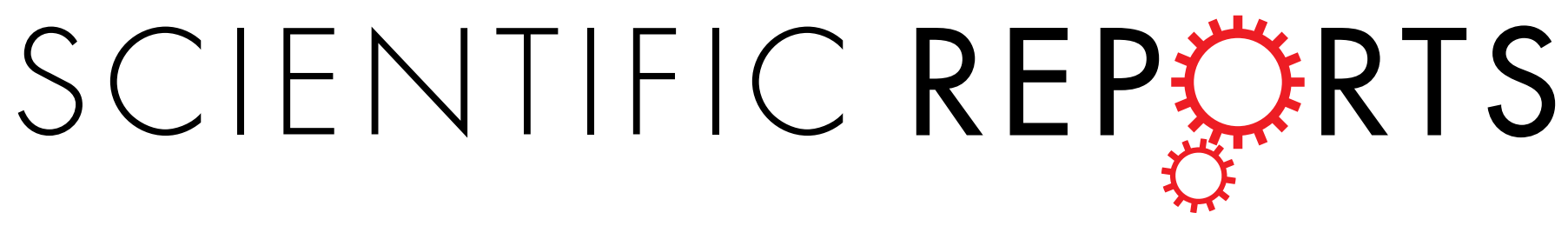

\title{
OPEN Hydrogen peroxide-based products alter inflammatory and tissue damage-related proteins in the \\ gingival crevicular fluid of healthy volunteers: a randomized trial
}

Received: 17 October 2018

Accepted: 4 February 2019

Published online: 05 March 2019

\author{
Valderlane L. P. Colares ${ }^{1}$, Suellen N. L. Lima ${ }^{1}$, Nágila C. F. Sousa ${ }^{1}$, Mizael C. Araújo ${ }^{1}$, \\ Domingos M. S. Pereira ${ }^{1}$, Saulo J. F. Mendes ${ }^{1}$, Simone A. Teixeira ${ }^{2}$, Cristina de A. Monteiro ${ }^{1}$, \\ Matheus C. Bandeca ${ }^{1}$, Walter L. Siqueira ${ }^{3}$, Eduardo B. Moffa ${ }^{1,3,4}$, Marcelo N. Muscará ${ }^{2}$ \& \\ Elizabeth S. Fernandes ${ }^{1}$
}

Hydrogen peroxide $\left(\mathrm{H}_{2} \mathrm{O}_{2}\right)$-based products are effective in tooth whitening; however, their safety is controversial as they may harm patient tissues/cells. These effects are suggested to be concentrationdependent; nonetheless, to date, there are no reports on $\mathrm{H}_{2} \mathrm{O}_{2}$-mediated oxidative damage in the gingival tissue, and neither whether this can be detected in gingival crevicular fluid (GCF) samples. We hypothesize that $\mathrm{H}_{2} \mathrm{O}_{2}$ whitening products may cause collateral oxidative tissue damage following in office application. Therefore, $\mathrm{H}_{2} \mathrm{O}_{2}$ and nitric oxide (NO) levels were investigated in $\mathrm{GCF}$ samples obtained from patients undergoing dental bleaching with $\mathrm{H}_{2} \mathrm{O}_{2}$ at different concentrations, in a randomized, double-blind, split-mouth clinical trial. A proteomic analysis of these samples was also performed. $\mathrm{H}_{2} \mathrm{O}_{2}$-based whitening products promoted inflammation which was detected in GCF samples and lasted for longer following $35 \% \mathrm{H}_{2} \mathrm{O}_{2}$ bleaching. This included time-dependent changes in $\mathrm{NO}$ levels and in the abundance of proteins associated with NO synthesis, oxidative stress, neutrophil regulation, nucleic acid damage, cell survival and/or tissue regeneration. Overall, $\mathrm{H}_{2} \mathrm{O}_{2}$-based products used in office promote inflammation irrespective of their concentration. As the inflammation caused by $35 \% \mathrm{H}_{2} \mathrm{O}_{2}$ is longer, patients may benefit better from using lower concentrations of this bleaching product, as they may result in less tissue damage.

Tooth whitening is currently a widely performed procedure, especially in the dental office. This is due to the increased awareness on that, aesthetically, white and well aligned teeth are standards of an ideal smile ${ }^{1}$. The techniques used for tooth whitening employ different whitening products which can be applied to the dental surface in varying concentrations and time of exposure ${ }^{2-5}$. The most commonly used whitening products are those containing hydrogen peroxide $\left(\mathrm{H}_{2} \mathrm{O}_{2}\right)$ or carbamide peroxide at different concentrations $(10-38 \%)^{6}$.

Despite the clinical efficacy of the in office whitening procedures ${ }^{5}$, adverse effects have been described for their usage including dental sensitivity ${ }^{6-8}$, soft tissue alterations ${ }^{9}$, genotoxicity ${ }^{10,11}$, pulp damage ${ }^{12,13}$, citotoxicity $^{14-16}$, in addition to gingival irritation ${ }^{6,17}$. The inflammatory effects of tooth whitening products have also been studied; however, the evidences gathered to date are controversial ${ }^{9,18-21}$.

$\mathrm{H}_{2} \mathrm{O}_{2}$-based tooth whitening products are most frequently used in office ${ }^{6,22,23}$. Their efficacy is suggested to be concentration-dependent. Indeed, the higher the concentration of $\mathrm{H}_{2} \mathrm{O}_{2}$, the greater the occurrence of oxidative reactions, which in turn, result in the removal of tooth pigmentation ${ }^{13,24-26}$. Although there are no in vivo 


\begin{tabular}{|l|c|c|c|l|}
\hline & \multicolumn{3}{|c|}{$\mathbf{1 5} \% \mathbf{H}_{2} \mathbf{O}_{2}(\mathbf{M e a n} \pm \mathbf{S E})$} & \multicolumn{2}{l|}{$\mathbf{3 5} \% \mathbf{H}_{2} \mathbf{O}_{2}$ (Mean $\left.\pm \mathbf{S E}\right)$} \\
\cline { 2 - 5 } & $\mathbf{7}$ days & $\mathbf{2 1}$ days & $\mathbf{7}$ days & $\mathbf{2 1}$ days \\
\hline$\Delta \mathrm{E}$ (Vita Easyshade) & $5.9 \pm 0.7$ & $6.6 \pm 0.77$ & $5.87 \pm 0.97$ & $6.88 \pm 0.6$ \\
\hline$\Delta \mathrm{SGU}$ (Vita Bleached) & $2.22 \pm 0.23$ & $3.59 \pm 0.39 *$ & $2.4 \pm 0.25$ & $4.00 \pm 0.30^{*}$ \\
\hline$\Delta \mathrm{SGU}$ (Vita Classic) & $4.72 \pm 0.46$ & $5.27 \pm 0.52$ & $5.04 \pm 0.53$ & $5.86 \pm 0.51$ \\
\hline
\end{tabular}

Table 1. Clinical efficacy of tooth whitening products containing $15 \%$ or $35 \% \mathrm{H}_{2} \mathrm{O}_{2}$. Clinical efficacy was determined by qualitative (Vita Classic and Vita Bleachedguide) and quantitative (spectrophotometry by Vita Easyshade). Data were collected before (baseline) and at different time-points after the bleaching procedures. Shade guide units (SGU). Mean \pm standard error (SE); $* \mathrm{p}<0.05$; differs from day 7.

\begin{tabular}{|l|l|l|l|l|}
\hline \multirow{2}{*}{} & \multicolumn{2}{|l|}{$\mathbf{1 5 \%} \mathrm{H}_{\mathbf{2}} \mathbf{O}_{\mathbf{2}}($ Mean $\pm \mathbf{S E})$} & \multicolumn{2}{l|}{$\mathbf{3 5} \% \mathbf{H}_{\mathbf{2}} \mathbf{O}_{\mathbf{2}}($ Mean $\pm \mathbf{S E})$} \\
\cline { 2 - 5 } & $\mathbf{1}^{\text {st }}$ session & $\mathbf{2}^{\text {nd }}$ sesssion & $\mathbf{1}^{\text {st }}$ session & $\mathbf{2}^{\text {nd }}$ sesssion \\
\hline 1 h post-session & $1.22 \pm 0.45$ & $1.10 \pm 0.49$ & $4.33 \pm 0.72^{*}$ & $4.47 \pm 0.72^{*}$ \\
\hline 24h post-session & $0.25 \pm 0.18$ & $0.45 \pm 0.31$ & $1.54 \pm 0.44$ & $1.67 \pm 0.47$ \\
\hline
\end{tabular}

Table 2. Tooth sensitivity following application of whitening products containing $15 \%$ or $35 \% \mathrm{H}_{2} \mathrm{O}_{2}$. Tooth sensitivity was assessed by the visual analogue scale (VAS). Data were collected at $1 \mathrm{~h}$ and $24 \mathrm{~h}$ post each bleaching procedure. Mean \pm standard error $(\mathrm{SE}) ; * \mathrm{p}<0.05$; differs from the $15 \% \mathrm{H}_{2} \mathrm{O}_{2}$ group.

evidences on whether tooth whitening causes oxidative damage in the gingival tissue, in vitro studies have suggested that $\mathrm{H}_{2} \mathrm{O}_{2}$ from bleaching gels may diffuse through the enamel/dentin and thus, reduce fibroblast ${ }^{27}$ and odontoblast ${ }^{28}$ viability.

Oxidative stress occurs during inflammation as a result of an excessive generation of oxidants and/or reduced antioxidant defense mechanisms ${ }^{29-31}$, leading to increased tissue damage. In vivo produced oxidant species may be solely derived from molecular oxygen, such as $\mathrm{H}_{2} \mathrm{O}_{2}$, superoxide anion $\left(\mathrm{O}_{2}^{-}\right)$and hydroxil radical (HO), being this later the most reactive and deleterious reactive oxygen species (ROS $)^{30}$, or even result from the combined reaction with the free radical nitric oxide $(\mathrm{NO})^{30}$. In fact, $\mathrm{NO}$ can react with $\mathrm{O}_{2}^{-}$to produce peroxynitrite $\left(\mathrm{ONOO}^{-}\right)$, which in turn may cause tissue damage by altering (oxidizing) DNA, lipids and proteins leading to the consequent loss of function ${ }^{30}$. The highly oxidant and bactericidal agent hypochlorous acid $(\mathrm{HClO})$ is produced from myeloperoxidase (MPO), an enzyme present in the neutrophil azurophillic granules, by catalizing the oxidation of chloride $\left(\mathrm{Cl}^{-}\right)$anion by $\mathrm{H}_{2} \mathrm{O}_{2}{ }^{32}$.

We hypothesize that $\mathrm{H}_{2} \mathrm{O}_{2}$ whitening products may cause collateral oxidative tissue damage following in office application. Therefore, the levels of $\mathrm{H}_{2} \mathrm{O}_{2}$ and $\mathrm{NO}$ were investigated in gingival crevicular fluid (GCF) samples obtained from patients undergoing in office dental bleaching. A proteomic analysis of these samples was also performed.

\section{Results}

The efficacy of $\mathrm{H}_{2} \mathrm{O}_{2}$-containing products does not depend on the used concentration. Twentytwo of the initially recruited individuals continued through the research protocol (15\% drop-off; 3 out of 25 subjects). Of note, baseline tooth shades were similar amongst individuals (7.30 \pm 2.6 shade guide units (SGU)). The Table 1 shows that the commercially available $\mathrm{H}_{2} \mathrm{O}_{2}$-containing dental bleaching products (containing 15 and $35 \% \mathrm{H}_{2} \mathrm{O}_{2}$ ) presented similar efficacy, as evaluated 7 and 21 days after the first application by the Vita Bleachedguide technique. Despite effective, the dental bleaching products did not produce differences over time, when evaluated by the Vita Classic and Vita Easyshade techniques.

$35 \% \mathrm{H}_{2} \mathrm{O}_{2}$ promotes greater tooth sensitivity than $15 \% \mathrm{H}_{2} \mathrm{O}_{2}$ bleaching. Table 2 shows the effects of in office dental bleaching with $\mathrm{H}_{2} \mathrm{O}_{2}$ on tooth sensitivity. Both tested concentrations of $\mathrm{H}_{2} \mathrm{O}_{2}$ promoted tooth sensitivity; a response that was more pronounced (by 3.7-fold) following application of $35 \% \mathrm{H}_{2} \mathrm{O}_{2}$ in comparison with $15 \% \mathrm{H}_{2} \mathrm{O}_{2}$.

GCF samples present with higher neutrophil contents and lower $\mathrm{NO}_{\mathrm{x}}^{-}$concentrations after $\mathrm{H}_{2} \mathrm{O}_{2}$ bleaching. Figure $1 \mathrm{~A}$ depicts $\mathrm{NO}_{\mathrm{x}}^{-}$concentrations measured in the GCF samples obtained before and after dental bleaching with $\mathrm{H}_{2} \mathrm{O}_{2}$ at 15 and $35 \%$. Whilst no differences were observed over time after the application of $15 \% \mathrm{H}_{2} \mathrm{O}_{2}$, the application of $35 \% \mathrm{H}_{2} \mathrm{O}_{2}$ resulted in significant reduction ( $\left.31 \%\right)$ of $\mathrm{GCF} \mathrm{NO}_{\mathrm{x}}^{-}$concentrations from the day 1 to 7 after the first session. After the second bleaching session, the $\mathrm{GCF} \mathrm{NO}_{\mathrm{x}}^{-}$concentrations were similar to those detected at baseline. No significant changes were observed in $\mathrm{GCF}_{2} \mathrm{O}_{2}$ concentrations due to the bleaching procedures, despite the trend to lower values observed 7 days after the first session (Fig. 1B).

Also, MPO contents were raised (22-fold increase) in GCF samples of patients who had undergone bleaching with $\mathrm{H}_{2} \mathrm{O}_{2}$ in comparison baseline measurements, independently of the used concentration (Fig. 1C). 

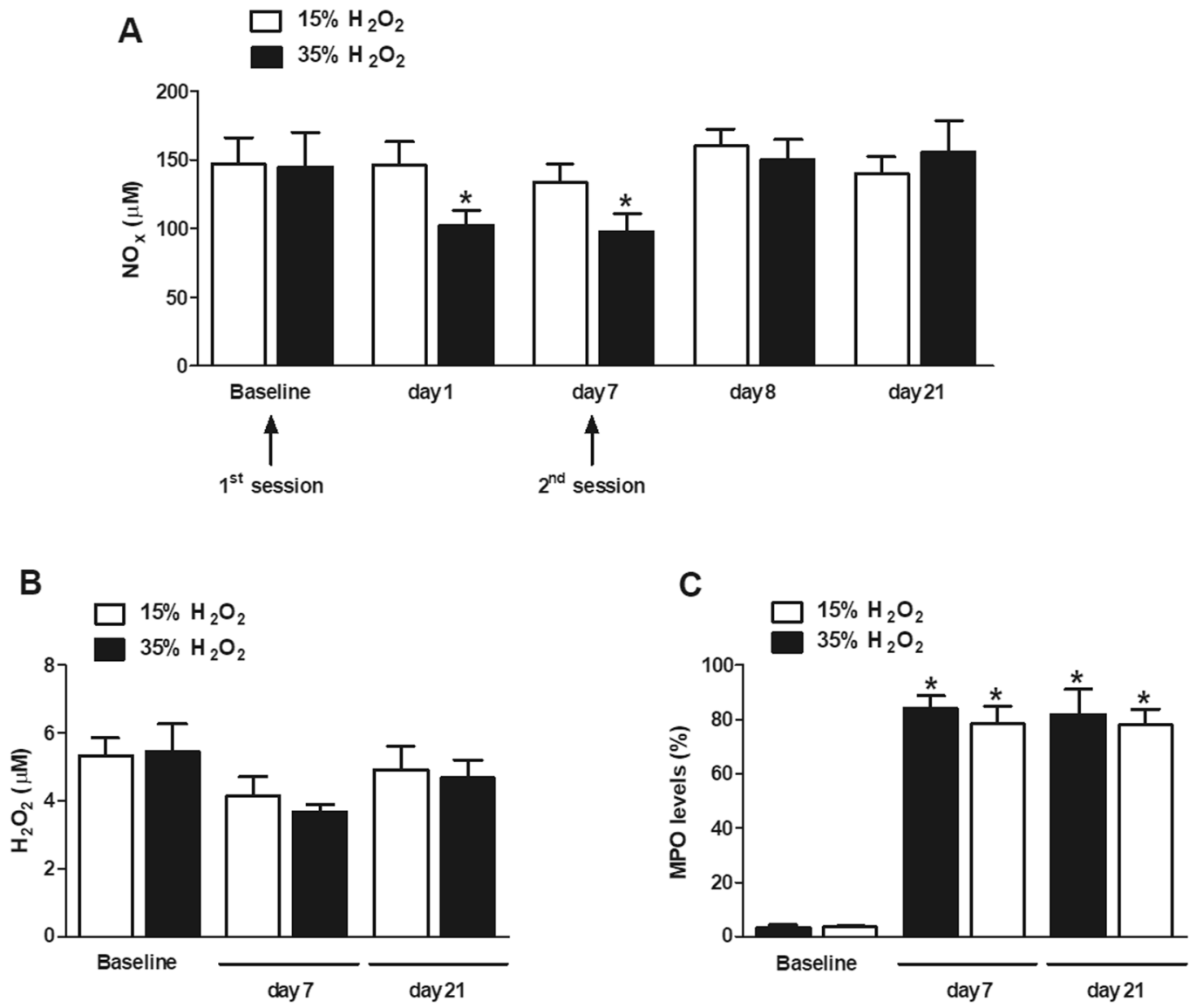

Figure 1. Analysis of gingival crevicular fluid markers in patients undergoing a 2-session tooth whitening with products containing hydrogen peroxide $\left(\mathrm{H}_{2} \mathrm{O}_{2}, 15-35 \%\right)$. Nitric oxide end-product $\left(\mathrm{NO}_{\mathrm{x}}^{-}=\mathrm{NO}_{2}^{-}+\mathrm{NO}_{3}^{-}\right)$ concentrations (panel A), $\mathrm{H}_{2} \mathrm{O}_{2}$ concentrations (panel B) and myeloperoxidase (MPO) contents (panel C) were measured in gingival crevicular fluid samples collected before (baseline) and at different time-points after dental bleaching. ${ }^{*} \mathrm{p}<0.05$ vs. the corresponding baseline values.

Proteomic analysis. Proteins related to NO synthesis, oxidative stress, neutrophil regulation, nucleic acid damage, cell survival and/or tissue regeneration accounted for $\sim 25 \%$ of all detected proteins in both groups of patients over the observation period.

Proteomic analysis detected 257 proteins in baseline samples obtained from subjects exposed to $15 \% \mathrm{H}_{2} \mathrm{O}_{2}$. Post-bleaching, there was a decline in protein abundance with subjects presenting 222 (13.6\% reduction) and 154 ( $40.1 \%$ reduction) proteins. Amongst the detected proteins (Supplementary Table 1), there was an increase in the percentage of proteins related with NO synthesis (from $0 \%$ at baseline conditions to $1.3 \%$ at 21 days post- $1^{\text {st }}$ session), oxidative stress (from $3.9 \%$ at baseline conditions to $5.8 \%$ at 21 days post- $1^{\text {st }}$ session), neutrophil regulation (from $2.3 \%$ at baseline conditions to $6.5 \%$ at 21 days post- $1^{\text {st }}$ session) and cell survival (from $9.7 \%$ at baseline conditions to $11.7 \%$ at 21 days post- $1^{\text {st }}$ session; Table 3 ).

On the other hand, the same samples presented with a transient increase of proteins related with nucleic acid damage (from $3.9 \%$ at baseline conditions to $4.5 \%$ at 7 days post- $1^{\text {st }}$ session), with this group of proteins representing $2.6 \%$ of the total proteins detected at the end of the observation period ( 21 days post- $1^{\text {st }}$ session; Table 3 ). Similarly, there was a transient reduction in the percentage of proteins associated with tissue regeneration, as $6.6 \%$ were observed in pre-bleaching conditions and $2.3 \%$ and $6.5 \%$ were registered at days 7 and 21 post- $1^{\text {st }}$ session, respectively (Table 3).

The GCF samples obtained from patients submitted to $35 \% \mathrm{H}_{2} \mathrm{O}_{2}$ bleaching were also evaluated. From the 353 proteins detected at pre-bleaching conditions, 255 (27.8\% reduction) and 225 (36.3\% reduction), were observed for days 7 and 21 post- $1^{\text {st }}$ session. Of the detected proteins (Supplementary Table 2), a progressive increase was observed in the percentage of proteins associated with oxidative stress (from $1.7 \%$ at baseline conditions to $2.7 \%$ at 21 days post- $1^{\text {st }}$ session). The percentage of proteins associated with neutrophil regulation was stable until the $7^{\text {th }}$ day post- ${ }^{\text {st }}$ session of bleaching, diminishing after 21 days (from $2.6 \%$ at baseline conditions to $1.3 \%$ at 21 days post- $1^{\text {st }}$ session). A similar profile was noted for proteins involved in tissue regeneration (from $5.4 \%$ at baseline conditions to $3.6 \%$ at 21 days post- $1^{\text {st }}$ session; Table 3 ).

On the contrary, the same samples exhibited a transient increase of proteins associated with damage of nucleic acids from $2.0 \%$ at baseline conditions to $3.1 \%, 7$ days post- $1^{\text {st }}$ session, with their levels returning to $2.2 \%$ at the end of the observation period (21 days post- $1^{\text {st }}$ session) (Table 3 ). A similar response was observed for proteins 


\begin{tabular}{|l|l|l|l|l|l|l|l|}
\hline \multicolumn{2}{|c|}{} & $\begin{array}{l}\text { NO } \\
\text { synthesis }\end{array}$ & $\begin{array}{l}\text { Oxidative } \\
\text { stress }\end{array}$ & $\begin{array}{l}\text { Neutrophil } \\
\text { regulation }\end{array}$ & $\begin{array}{l}\text { Nucleic acid } \\
\text { damage }\end{array}$ & $\begin{array}{l}\text { Cell } \\
\text { survival }\end{array}$ & $\begin{array}{l}\text { Tissue } \\
\text { regeneration }\end{array}$ \\
\hline \multirow{3}{*}{$15 \% \mathrm{H}_{2} \mathrm{O}_{2}$} & Baseline & $0 \%$ & $3.9 \%$ & $2.3 \%$ & $3.9 \%$ & $9.7 \%$ & $6.6 \%$ \\
\cline { 2 - 8 } & 7 days & $1.4 \%$ & $4.5 \%$ & $3.2 \%$ & $4.5 \%$ & $10.4 \%$ & $2.3 \%$ \\
\cline { 2 - 8 } & 21 days & $1.3 \%$ & $5.8 \%$ & $6.5 \%$ & $2.6 \%$ & $11.7 \%$ & $6.5 \%$ \\
\hline \multirow{2}{*}{$35 \% \mathrm{H}_{2} \mathrm{O}_{2}$} & Baseline & $0.3 \%$ & $1.7 \%$ & $2.6 \%$ & $2.0 \%$ & $8.8 \%$ & $5.4 \%$ \\
\cline { 2 - 8 } & 7 days & $0.8 \%$ & $2.4 \%$ & $2.8 \%$ & $3.1 \%$ & $8.6 \%$ & $5.5 \%$ \\
\cline { 2 - 8 } & 21 days & $0.4 \%$ & $2.7 \%$ & $1.3 \%$ & $2.2 \%$ & $8.9 \%$ & $3.6 \%$ \\
\hline
\end{tabular}

Table 3. Abundance of proteins associated with NO synthesis, oxidative stress, neutrophil regulation, nucleic acid damage, cell survival and tissue regeneration in GCF samples obtained from patients undergoing dental bleaching with $\mathrm{H}_{2} \mathrm{O}_{2}$ (15 or 35\%). Samples were collected prior (baseline) and at different time-points after the bleaching process initiated. Results are expressed as percentage (\%) in relation with the total number of proteins detected in each time-point.

associated with NO production, with these proteins representing $0.3 \%$ of the detected proteins at baseline conditions, and then, $0.8 \%$ and $0.4 \%$, at days 7 and 21 post- $1^{\text {st }}$ session, respectively (Table 3 ). Proteins associated with cell survival remained stable throughout the bleaching procedure (8.6-8.9\%; Table 3 ).

Amongst the evaluated classes of proteins, some of them participate in different processes, as observed in Supplementary Tables 1 and 2. The Venn diagrams (Figs 2 and 3), show the dynamics of the detected proteins over the observation period, with different proteins participating in a process at specific time-points.

\section{Discussion}

Previous studies have shown that $\mathrm{H}_{2} \mathrm{O}_{2}$-containing tooth whitening products present similar efficacy irrespective of the concentration used ${ }^{5}$. Here, the efficacy of the products tested was confirmed by Vita Bleachedguide, Vita Classic and Vita Easyshade analysis, although time-dependent effects were only observed by using the Vita Bleachedguide technique. Indeed, this analysis showed a greater efficacy 21 days after the first session.

Although effective, the safety of the application of $\mathrm{H}_{2} \mathrm{O}_{2}$ gels is of debate, as deleterious effects in the patient tissues/cells have been suggested for these products, including dental sensitivity ${ }^{6-8}$, cytotoxicity ${ }^{14-16}$ and genotoxicity $^{10,11}$, pulp damage ${ }^{12,13}$ and gingival irritations $s^{6,17}$, amongst others. Evidences also suggest that inflammation may occur following the application of dental bleaching, specially at pulp level ${ }^{9,18,19,21,33}$. These effects are suggested to be concentration-dependent; however, to date, there are no reports on $\mathrm{H}_{2} \mathrm{O}_{2}$-mediated oxidative damage in the gingival tissue, or neither whether this may be relevant enough to be detected in a timely manner in GCF samples.

In this study, we show for the first time that tooth whitening products containing $\mathrm{H}_{2} \mathrm{O}_{2}$ promote pro-inflammatory alterations able to be detected in GCF samples collected by following a simple and non-invasive procedure. The GCF is an exudate rich in serum, leukocytes, structural cells and microorganisms, considered as a potential indicator of an ongoing inflammation and monitoring tool post-dental procedures ${ }^{34-36}$. Of note, GCF samples composing the test groups presented different amounts of proteins at baseline conditions. Although obtained from the same group of individuals, it is possible that daily dental care influences the composition of GCF; for instance, one may exert different forces when brushing different sides of the mouth. Indeed, mechanical stimuli such as vigorous brushing are known to affect the volume and composition of GCF samples ${ }^{37}$.

The ability of $\mathrm{H}_{2} \mathrm{O}_{2}$-based bleaching gels to cause inflammation is not novel. Indeed, previous studies demonstrated that the in office application of high concentrations of $\mathrm{H}_{2} \mathrm{O}_{2}(35-38 \%)$ causes pulp inflammation characterized by leukocyte migration, angiogenesis and tissue damage ${ }^{21,33}$, and that this effect is concentration-dependent with less damage occurring with the lowest concentrations of the bleaching product. On the other hand, evidences on gingival inflammation following in office tooth whitening are controversial, as this effect may depend on exposure conditions to $\mathrm{H}_{2} \mathrm{O}_{2}$ such as trays and use of light during the procedure ${ }^{19,38}$. Also, a recent report using a similar bleaching protocol to the one used herein, analyzed the levels of cytokines in GCF samples; the study suggested that $\mathrm{H}_{2} \mathrm{O}_{2}$-based gels do not cause inflammation at $\mathrm{GFC} \mathrm{level}^{20}$. In this study, a significant reduction in the GCF $\mathrm{NO}_{\mathrm{x}}^{-}$concentrations was detected only in patients who underwent bleaching with $35 \% \mathrm{H}_{2} \mathrm{O}_{2}$. This effect was observed as soon as 1 day after the first dental bleaching session and remained low during the next 7 days. On the other hand, after the $2^{\text {nd }}$ session, these concentrations returned to those observed at baseline conditions. A similar profile, although less pronounced and of no statistical significance, was observed for $\mathrm{GCF}_{2} \mathrm{O}_{2}$ concentrations for both bleaching products. On the contrary, GCF neutrophil contents (as assessed by MPO levels) were raised in patients undergoing bleaching, irrespective of either the $\mathrm{H}_{2} \mathrm{O}_{2}$ concentration or the time of evaluation. These data indicate that, at the 15-35\% range concentration, $\mathrm{H}_{2} \mathrm{O}_{2}$ causes inflammation; however, the mediators and pathways involved in this response may depend on its concentration.

The proteomic analysis of the GCF samples showed that dental bleaching causes alterations in the abundance of proteins associated not only with $\mathrm{NO}$ and $\mathrm{H}_{2} \mathrm{O}_{2}$ synthesis, but also with neutrophil recruitment. Proteins associated with NO synthesis and oxidative stress were increased following bleaching, irrespective of $\mathrm{H}_{2} \mathrm{O}_{2}$ concentration.

Mitochondrial NADH dehydrogenase ubiquinone flavoprotein 3, involved in NO synthesis, was detected in samples obtained from of both groups of bleaching. Other proteins related to NO synthesis such as mitogen-activated protein kinase kinase kinase 4, NADH-ubiquinone oxidoreductase chain 2, mitochondrial $\mathrm{NADH}$ dehydrogenase ubiquinone flavoprotein 3 and TIR-domain containing adaptor molecule 1 were found in GCF samples following tooth whitening with $15 \% \mathrm{H}_{2} \mathrm{O}_{2}$; whilst NADH-ubiquinone oxidoreductase subunit 5 was only detected in those who received $35 \% \mathrm{H}_{2} \mathrm{O}_{2}$. 
A- NO synthesis

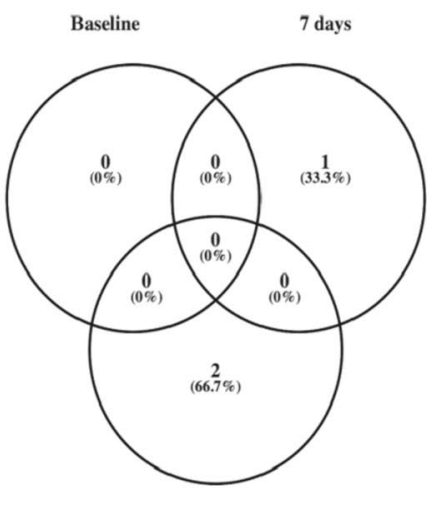

21 days

\section{C-Neutrophil regulation}

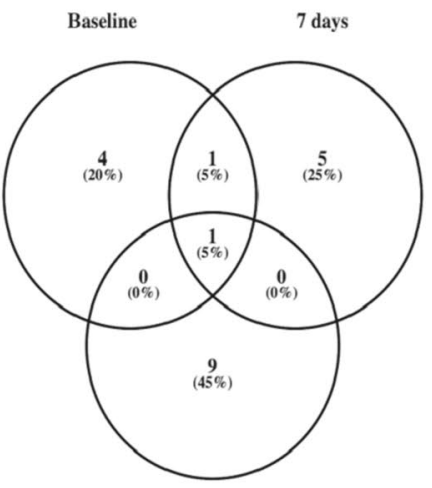

21 days

\section{E-Cell survivall}

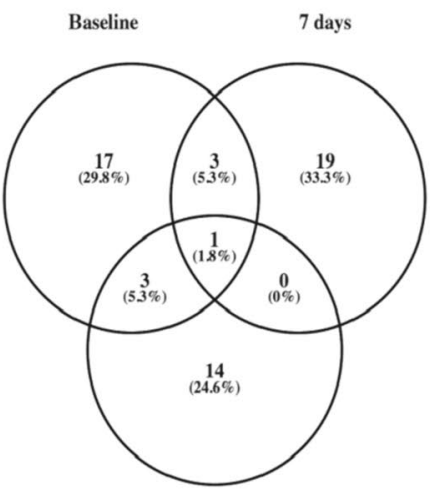

21 day

\section{B-Oxidativestress}

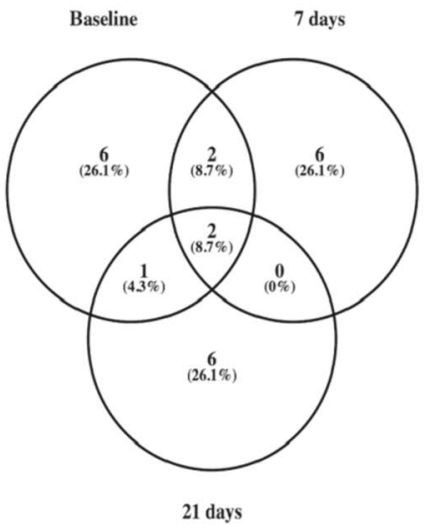

D- Nucleic acid damage

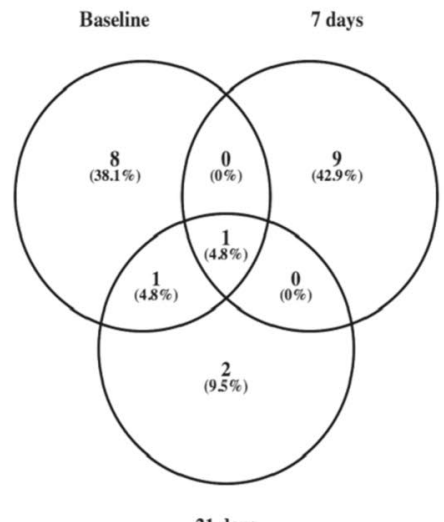

F- Tissue regeneration

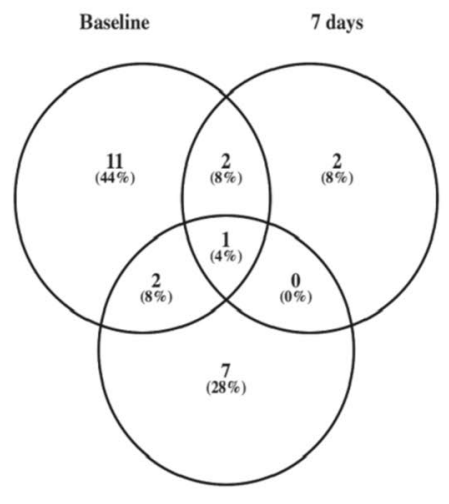

21 days

Figure 2. Time-dependent abundance of proteins detected in gingival crevicular fluid samples obtained from patients undergoing a 2-session tooth whitening with hydrogen peroxide $\left(\mathrm{H}_{2} \mathrm{O}_{2}, 15 \%\right)$. Proteins were classified by biological function as associated with: $\mathrm{NO}$ synthesis, oxidative stress, neutrophil regulation, nucleic acid damage, cell survival and tissue regeneration. Samples were collected before (baseline) and at different timepoints after dental bleaching.

Oxidoreductases such as JHDM1D, NADH-ubiquinone oxidoreductase chain 2, NADH-ubiquinone oxidoreductase subunit 5, NADH dehydrogenase [ubiquinone] flavoprotein 3, dehydrogenase/reductase 2-isoform 2, retinol dehydrogenase 14, epydidimal secretory protein $\mathrm{Li}$ 55, mitochondrial peroxiredoxin-5 and EGLN3, and the antioxidant protein S100-A8 were detected in GCF samples at the day 7 post- $1^{\text {st }}$ session with $\mathrm{H}_{2} \mathrm{O}_{2}$. Despite 
A-NO synthesis

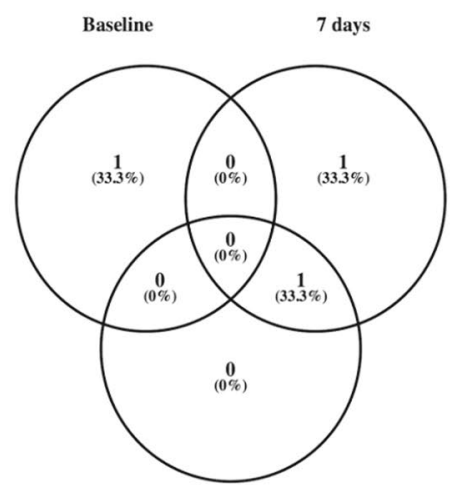

21 days

\section{C-Neutrophil regulation}

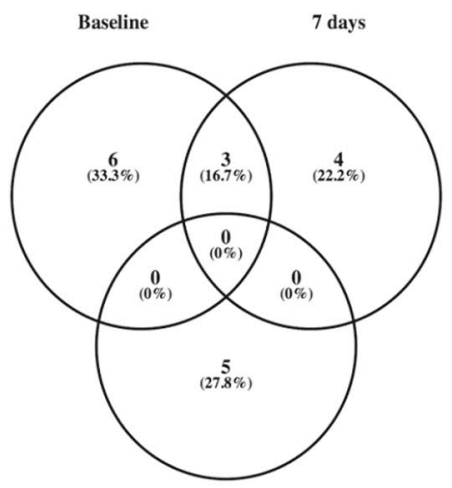

21 days

E-Cell survivall

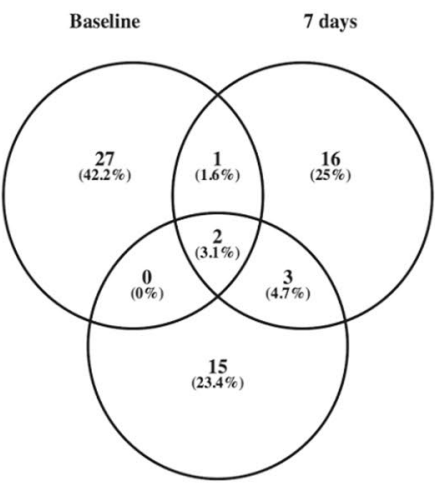

21 days

\section{B-Oxidative stress}

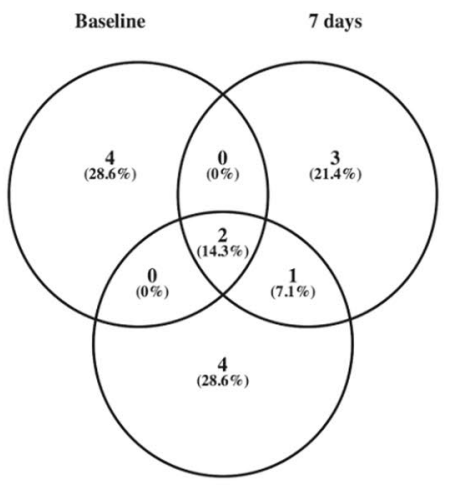

21 days

\section{D- Nucleic acid damage}

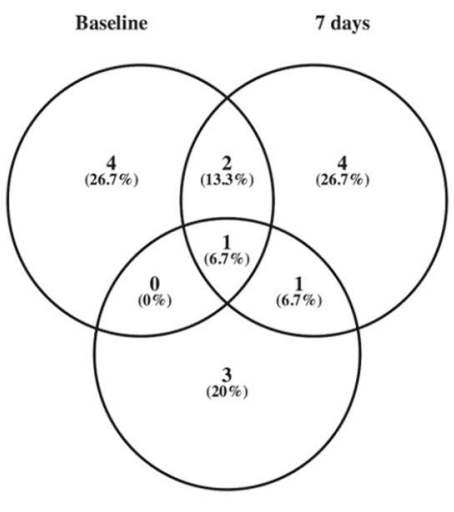

21 days

\section{F- Tissue regeneration}

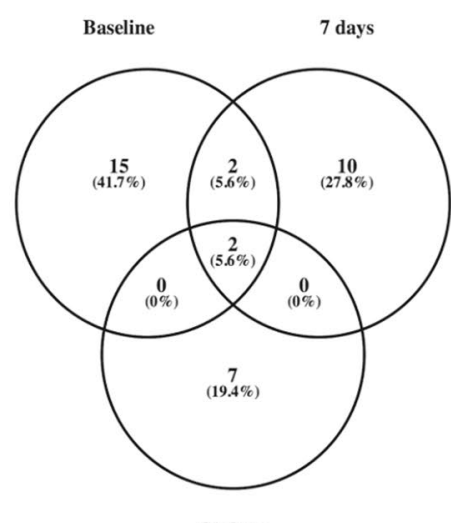

Figure 3. Time-dependent abundance of proteins detected in gingival crevicular fluid samples obtained from patients undergoing a 2-session tooth whitening with hydrogen peroxide $\left(\mathrm{H}_{2} \mathrm{O}_{2}, 35 \%\right)$. Proteins were classified by biological function as associated with: NO synthesis, oxidative stress, neutrophil regulation, nucleic acid damage, cell survival and tissue regeneration. Samples were collected before (baseline) and at different timepoints after dental bleaching.

the detection of oxidoreductases such as cytocrome P450 2D6, NADH dehydrogenase ubiquinone flavoprotein 3, EGLN3, the epydidimal secretory protein Li 55 and the antioxidant protein S100-A8; at 21 days post- ${ }^{\text {st }}$ session, the samples were also positive for annexin and transient receptor potential channels M2 and V1, proteins involved in the sensing and production of oxidant molecules ${ }^{39-42}$. This alteration in the expression of regulators of $\mathrm{NO}$ synthesis and oxidative stress, explains, at least in part, the profile of $\mathrm{NO}$ and $\mathrm{H}_{2} \mathrm{O}_{2}$ release in patients after bleaching. 
Different proteins that regulate neutrophil chemotaxis, activation and degranulation were detected in GCF samples in both pre- and post-bleaching conditions. The largest abundance of proteins of these classes was observed for patients who had undergone $15 \% \mathrm{H}_{2} \mathrm{O}_{2}, 21$ post- $1^{\text {st }}$ session. GCF samples obtained from patients treated with either 15 or $35 \% \mathrm{H}_{2} \mathrm{O}_{2}$ presented proteins associated with the activation and degranulation of neutrophils (keratin 1, S100-A8, eosinophil cationic protein, neutrophil defensin, tyrosine-phosphatase beta receptor-like, TIR-domain containing adaptor molecule 1 and resistin) at this time point; however, proteins related with neutrophil chemotaxis and death (inositol-trisphosphate 3-kinase $\mathrm{B}$ and annexin) were only detected in the $15 \% \mathrm{H}_{2} \mathrm{O}_{2}$ bleaching treatment. Pre-bleaching conditions presented proteins associated with neutrophil migration, activation and degranulation (beta-defensin 119, NF-kappa-B subunit p105, kinase serine/threonine protein 10, hornerin, calcium/calmodulin-dependent kinase type 1D, Ig variable chain 3-11, S100-A8, maltase-glucoamylase, phospholipid-transporting ATPase 8AI, N-acetylgalactosamin-6-sulphatase and $\mathrm{N}$-acylesphingosine amidohydrolase 1 ).

For both $\mathrm{H}_{2} \mathrm{O}_{2}$ concentrations tested, there was an increase in the abundance of proteins related with nucleic acid damage, 7 days post- $1^{\text {st }}$ session, but an increase in the percentage of cell survival proteins was only observed following $15 \%$ bleaching in comparison with pre-whitening conditions. Tissue regeneration proteins were reduced at 7 days for the $15 \%$ and 21 days for the $35 \%$ bleaching.

Twenty one days following the $1^{\text {st }}$ session of bleaching, there was a restoration in the percentage of GCF proteins related to tissue regeneration (angiogenesis, re-epithelialization, fibroblast proliferation, neuronal regeneration, osteoclastogenesis and dentin production) only in those undergoing bleaching with the lowest concentration of $\mathrm{H}_{2} \mathrm{O}_{2}$. These evidences allow us to suggest the existence of an inflammatory process that is more exacerbated following tooth whitening with $35 \% \mathrm{H}_{2} \mathrm{O}_{2}$, and lasts for the whole observation period.

According to these findings ( $\mathrm{NO}$ and $\mathrm{H}_{2} \mathrm{O}_{2}$ levels and proteome), and considering that both $\mathrm{NO}$ and $\mathrm{H}_{2} \mathrm{O}_{2}$ are constitutively produced by endothelial cells, neurons and/or keratinocytes ${ }^{43-45}$, we can suggest that the $35 \% \mathrm{H}_{2} \mathrm{O}_{2}$ bleaching may damage NO-producing cells (neurons and endothelial cells) and that both concentrations of $\mathrm{H}_{2} \mathrm{O}_{2}$ cause damage in $\mathrm{H}_{2} \mathrm{O}_{2}$-producing cells such as keratinocytes 7 days post- $1^{\text {st }}$ session. The observed reduction in $\mathrm{NO}$ levels at this time-point may be also due to its ability to react with with $\mathrm{O}_{2}^{-}$to produce peroxynitrite, which in turn, causes cell damage ${ }^{30}$.

In later time-points ( 21 days post- $1^{\text {st }}$ session), it was observed the restoration of the crevicular levels of NO and $\mathrm{H}_{2} \mathrm{O}_{2}$; this can be related to: $\mathrm{i}$ ) increased numbers of cell survival and tissue regeneration proteins, in addition to increased activation of neutrophils with 15\% bleaching; and ii) ongoing neutrophil activation and restoration of proteins associated with NO synthesis, and in parallel, a reduction in the abundance of regenerative proteins, following bleaching with either gel products.

Of note, evaluation of dental sensitivity demonstrated that a greater sensitization occurs following $35 \%$ in comparison with $15 \% \mathrm{H}_{2} \mathrm{O}_{2}$ bleaching; a response that was of similar magnitude following both bleaching sessions. The mechanisms of dental sensitivity are not fully understood; however, damage of dental pulp cells following $\mathrm{H}_{2} \mathrm{O}_{2}$ has been associated with increased tooth sensitivity ${ }^{12,13,27}$. Also, sensory nerve endings were previously found in areas of the inner dentin which are close to the pulp ${ }^{46,47}$. Thus, it is possible that products generated/ released during $\mathrm{H}_{2} \mathrm{O}_{2}$-induced pulp damage contribute to tooth hypersensitivity following tooth whitening.

Overall, our results show that in office tooth whitening procedures employing $\mathrm{H}_{2} \mathrm{O}_{2}$ present similar efficacy, however, they cause inflammation irrespective of the used concentration. As the inflammation caused by $35 \%$ $\mathrm{H}_{2} \mathrm{O}_{2}$ lasts for longer, patients may benefit better from using lower concentrations of this bleaching product, as they may result in less tissue damage.

\section{Methods}

Patients. The study was reviewed and approved by the Human Research Ethics Committee of the Universidade CEUMA (protocol number 1.307.220) and was performed in accordance with the Declaration of Helsinki 1975, as revised in 2008. The study was registered under the Brazilian Register of Clinical Assays (protocol number RBR-4kkcd7, registered in 05/11/2015, as "Evaluation of fluid gingival after bleaching with hydrogen peroxide in different strengths: clinical study randomized"). The primary outcome of the study was the tooth shade evaluation. Power analysis indicated that 22 patients were required in order to achieve a $90 \%$ chance of detecting a decrease in tooth shade by at least 2 SGU in comparison with baseline measurements $(\alpha=0.05)$. Sample size was calculated on the website www.sealedenvelope.com.

A total of 25 healthy subjects (18-40 years old) presenting pigmented (colour equal to or darker than A3) upper anterior teeth without sensitivity, were recruited for participation in the study. Tooth sensitivity to cold was evaluated as previously described ${ }^{20}$ by using the visual analogue scale (VAS; from $0-10$; with $0=$ no sensitivity and $10=$ maximum sensitivity), and it was also registered at $1 \mathrm{~h}$ and $24 \mathrm{~h}$ post each bleaching session. All subjects presented good general and oral health and hygiene, with no history of periodontal disease or gingival retractions, dental restorations or carious lesions, bruxism, dental sensitivity and had not recently taken analgesic and/ or anti-inflammatory drugs. Smokers, pregnant or lactating women, those who had previously undergone tooth whitening or endodontic treatment or had dental prosthesis or orthodontic appliances in the upper anterior teeth were excluded from the study. A written informed consent was obtained from each participant. A prophylaxis was performed in each participant on the week just prior to the beginning of the tooth whitening procedure.

Experimental groups. This study was a randomized, double-blinded, split-mouth clinical trial. The mouth of each participant was split with an equal allocation rate of $1: 1$ for one of two treatments $\left(\mathrm{H}_{2} \mathrm{O}_{2}, 15\right.$ and $35 \%$; block of 2). For this, treatments were labeled A and B, and were randomically assigned to each side of mouth of each subject by computer-generated tables prepared by a third person not involved in the research protocol (www.sealedenvelope.com). Both the participants and the experimenters were blinded to the protocol. Details of the allocated group were recorded on cards contained in sequentially numbered, opaque, sealed envelopes. 
The envelopes were opened by the patients on the day of bleaching to prevent disclosure of the randomization scheme. All gels were prepared according to the manufacturer's instructions by a third person who handled over to the operator, the gels according to their previous allocation as A or B. The study was conducted at the clinic of the School of Dentistry of Local University from March 2016 to August 2016; patients were recruited prior to the procedure, in March and April 2016.

Tooth whitening procedure. After prophylaxis, the initial color was registered and then, the bleaching procedure was performed. Before applying the whitening gel, the gingival tissue of the upper anterior teeth was isolated using a light-polymerized resin dam (Top Dam; FGM Prod. Odontol. Ltda., Joinville, SC, Brazil). The $\mathrm{H}_{2} \mathrm{O}_{2}$-containing bleaching products (Lase Peroxide Lite 15\% and Lase Peroxide Sensy 35\%; DMC Equip., São Carlos, SP, Brazil) were applied for $15 \mathrm{~min}$, three times in each session, without using light. Two bleaching sessions were performed with a 1-week interval between them. Participants were instructed to brush their teeth regularly using toothpaste without a desensitizing or bleaching agent. Bleaching efficacy was determined by comparison between the initial color shade and the one achieved post each session; by using the qualitative Vita Classic and Vita Bleachedguide 3D (Vita Zahnfabrik, Bad Säckingen, Germany) and the quantitative Vita Easyshade spectrophotometry (Vident, Brea, CA, USA) techniques. All patients were evaluated over 21 days post first session. Efficacy results were calculated as previously described ${ }^{20}$.

Collection of gingival crevicular fluid samples. Gingival crevicular fluid (GCF) samples were collected for analysis. For this, the soft tissues were isolated with cotton rolls and the upper anterior teeth were gently dried with air for 5-10 s. The GCF was collected from the teeth number 11 and 21, by using Perio-paper strips (IDE Interstate, Amityville, NY, USA). Two strips were individually inserted into the sulcus of each tooth (1-2 mm depth), for 60 seconds. Strips containing blood were discarded and a novel sample was then collected from a different site of the same tooth. After sample collection, strips were immediately placed in sterile Eppendorf tubes and the GCF samples were stored at $-80^{\circ} \mathrm{C}$ for further analysis. Samples were collected prior to (baseline), and 7 and 21 days after the beginning of the dental bleaching procedure.

Biochemical analysis of GCF samples. Sample preparation. Paper strips containing GCF samples (1 from each tooth) were incubated with $160 \mu \mathrm{l}$ of phosphate-buffered saline (PBS) for $10 \mathrm{~min}$, with vortexing at every $2 \mathrm{~min}$ of incubation. Then, samples were centrifuged at $1.200 \times \mathrm{g}$, for $5 \mathrm{~min}$. The resulting supernatants were collected and kept at $-80^{\circ} \mathrm{C}$ for further analysis of total $\mathrm{NO}_{2}^{-}+\mathrm{NO}_{3}^{-}$concentration $\left(\mathrm{NO}_{\mathrm{x}}^{-}\right.$; final products of NO oxidation), $\mathrm{H}_{2} \mathrm{O}_{2}$ and MPO levels (as a measurement of neutrophil contents).

Quantification of total $\mathrm{NO}_{x}$. Total $\mathrm{NO}_{\mathrm{x}}^{-}\left(\mathrm{NO}_{2}^{-} / \mathrm{NO}_{3}^{-}\right)$concentrations were measured by the Griess reaction method for $\mathrm{NO}_{2}^{-}$after the nitrate reductase-catalysed reduction of $\mathrm{NO}_{3}^{-}$to $\mathrm{NO}_{2}^{-}$, as previously described ${ }^{48}$. For this, $80 \mu \mathrm{l}$ of sample were incubated with $20 \mu \mathrm{l}$ of $1 \mathrm{U} / \mathrm{ml}$ nitrate reductase (Sigma-Aldrich) and $10 \mu \mathrm{l}$ of $1 \mathrm{mM}$ NADPH (Sigma-Aldrich) for $30 \mathrm{~min}$ at $37^{\circ} \mathrm{C}$, in a 96-well plate. Then, $100 \mu \mathrm{l}$ of Griess reagent (Sigma-Aldrich) were added and incubated for $15 \mathrm{~min}$ at $37^{\circ} \mathrm{C}$. Absorbance was measured at $550 \mathrm{~nm}$ immediately using a microplate reader (MB-580; Heales, Shenzhen, China). After subtraction of background readings, the absorbance in each sample was compared with that obtained from a sodium nitrite $(0-100 \mu \mathrm{M})$ standard curve. Results are expressed as $\mathrm{NO}_{\mathrm{x}}^{-}$concentrations in $\mu \mathrm{M}$.

Quantification of $\mathrm{H}_{2} \mathrm{O}_{2}$ concentrations. $\mathrm{H}_{2} \mathrm{O}_{2}$ concentrations in the GCF samples were measured by using a $\mathrm{H}_{2} \mathrm{O}_{2}$ /peroxidase assay kit (Amplex Red $\mathrm{H}_{2} \mathrm{O}_{2}$ /Peroxidase assay kit; Molecular Probes, Invitrogen), as previously described $^{48}$. Briefly, $50 \mu \mathrm{l}$ of the diluted GCF samples were incubated with $50 \mu \mathrm{l}$ of a solution containing $0.05 \mathrm{M}$ $\mathrm{NaH}_{2} \mathrm{PO}_{4}$ (pH 7.4), $0.2 \mathrm{U} / \mathrm{ml}$ horseradish peroxidase (HRP) and $25.7 \mathrm{mg} / \mathrm{ml}$ of the Amplex Red (10-acetyl-3,7dihydroxyphenoxazine) reagent, during $2 \mathrm{~h}$ at $37^{\circ} \mathrm{C}$. After the incubation, the absorbance of the reaction mixture was read at $560 \mathrm{~nm}$. Absorbance readings were compared with those obtained from a $\mathrm{H}_{2} \mathrm{O}_{2}$ standard curve $(0-40 \mu \mathrm{M})$. Results are expressed as $\mathrm{H}_{2} \mathrm{O}_{2}$ concentrations in $\mu \mathrm{M}$.

Measurement of MPO activity. MPO activity in GCF samples was assessed as an index of neutrophil influx, by measuring the speed of oxidation of $o$-dianisidine in the presence of $\mathrm{H}_{2} \mathrm{O}_{2}{ }^{49}$. Samples $(25 \mu \mathrm{l})$ were added of an equal volume of a potassium phosphate solution ( $5 \mathrm{mM}$; pH 6.0) containing 0.5\% HTAB (Sigma Chem. Co, USA). Then, the samples were sonicated for $20 \mathrm{~s}$ and incubated at $60^{\circ} \mathrm{C}$ for $2 \mathrm{~h}$, for inactivation of endogenous catalase. Then, samples were centrifuged at $10,000 \mathrm{~g}$ for $5 \mathrm{~min}$. An aliquot $(10 \mu \mathrm{l})$ of the supernatant was incubated with $200 \mu \mathrm{l}$ of potassium phosphate ( $\mathrm{pH}$ 6) containing $16.7 \mathrm{mg} / \mathrm{ml} o$-dianisidine (Sigma Chem. Co., EUA) and $0.0005 \% \mathrm{H}_{2} \mathrm{O}_{2}$ per well in a 96-well plate. The speed of the formation of the oxidation product of $o$-dianisidine was read at $460 \mathrm{~nm}$ every $10 \mathrm{~s}$ for $10 \mathrm{~min}$. MPO levels were calculated by comparing the initial and final registered absorbance. The results are expressed as the percentage (\%) of maximum speed of reaction in comparison with the initial absorbance of each sample.

Proteomic analysis. Sample preparation. For proteomic analysis, a pool of strips (1 from each tooth) obtained prior to and from each time-point after exposure with the different bleaching products, were incubated with $150 \mu \mathrm{l}$ of a solution containing $80 \%$ acetonitrile, $19.9 \%$ distilled water and $0.1 \%$ trifluoroacetic acid, and were then, sonicated 3 times for $1 \mathrm{~min}$. Samples were dried and ressuspended in $1000 \mu \mathrm{l}$ of distilled water. Total protein concentration was then, determined in each pool of samples by using the Micro BCA assay kit (Thermofisher, USA). Aliquots containing $10 \mu \mathrm{g} / \mathrm{pool}$ of sample were dried, denaturated and reduced by addition of $200 \mu \mathrm{l}$ of buffer 1 (containing $4 \mathrm{M}$ urea, $10 \mathrm{mM} \mathrm{DTT}$ and $50 \mathrm{mM} \mathrm{NH}_{4} \mathrm{HCO}_{3} ; \mathrm{pH} 7.8$ ). After $2 \mathrm{~h}$, samples were added of $1000 \mu \mathrm{l}$ of buffer $2\left(50 \mathrm{mM} \mathrm{NH}_{4} \mathrm{HCO}_{3}, \mathrm{pH}=7.8\right)$ and the proteins were digested for $18 \mathrm{~h}$ at $37^{\circ} \mathrm{C}$, with $2 \%(\mathrm{w} / \mathrm{w})$ 
sequencing-grade trypsin (Promega, Madison, WI, USA), samples were desalted (Zip Tip C-18, EMD Millipore Inc., Germany) and submitted to mass spectrometric analysis after HPLC separation (LC-ESI-MS/MS).

Liquid cromatography by mass spectrometry. Samples were resuspended in solvent A ( $97.5 \%$ distilled water $/ 2.4 \%$ acetonitrile $/ 0.1 \%$ formic acid) and then subjected to RP nLC-ESI-MS/MS, using a LTQ-Velos (Thermo Scientific, San Jose, CA, USA) mass spectrometer. LC aligned with the C18 column of capillary-fused silica (column length $10 \mathrm{~mm}$, column id $75 \mathrm{~m}, 3 \mathrm{~m}$ spherical beads, and $100 \mathrm{~A}^{\circ}$ pores size) was used, linked to the MS through electrospray ionization (ESI). The survey scan was set in the range of $\mathrm{m} / \mathrm{z}$ values $390-2000 \mathrm{MS} / \mathrm{MS}$. Peptides were eluted from the nanoflow reversed phase-high-performance liquid chromatography (RP-HPLC) over a 65 min period, with linear gradient ranging from 5 to $55 \%$ of solvent B ( $97.5 \%$ acetonitrile, $0.1 \%$ formic acid), at a flow rate of $300 \mathrm{nl} / \mathrm{min}$, with a maximum pressure of $280 \mathrm{bar}$. The electrospray voltage was $1.8 \mathrm{kV}$ and the temperature of the ion-transfer capillary was $300^{\circ} \mathrm{C}$. After a MS survey scan range within m/z 390-2000 was performed and after selection of the most intense ion (parent ion), MS/MS spectra were achieved via automated sequential selection of the seven peptides with the most intense ion for collision-induced dissociation (CID) at 35\% normalized collision energy, with the dynamic exclusion of the previously selected ions. The MS/MS spectra were matched with human protein databases (Swiss-Prot and TrEMBL, Swiss Institute of Bioinformatics, Geneva, Switzerland, https://ca.expasy.org/sprot/) using SEQUEST algorithm in Proteome Discoverer 1.3 software (Thermo Scientific, USA). The searches were performed by selecting the following SEQUEST parameters: (1) trypsin as protease enzyme, (2) $2 \mathrm{Da}$ precursor ion mass tolerance, (3) $0.8 \mathrm{Da}$ fragment ion mass tolerance, and (4) dynamic modifications of oxidized cysteine and methionine and phosphorylated serine and threonine. A maximum of four dynamic modifications per peptide were accepted. The SEQUEST score filter criteria applied to the MS/MS spectra for peptides were absolute XCorr threshold 0.4, fragment ion cutoff percentage 0.1 , and peptide without protein XCorr threshold 1.5. Any nontryptic peptides passing the filter criteria were discarded. Only proteins for which two or more peptides were identified are reported in this study.

Protein functions were assessed in the UniProt protein (https://www.uniprot.org/) and the National Center for Biotechnology Information (NCBI) gene (https://www.ncbi.nlm.nih.gov/) data banks, and literature search.

Statistical analysis. The results are presented as the mean \pm standard error (SE). Statistical comparison was performed by analysis of variance of repeated measures followed by the Bonferroni test. $\mathrm{p}<0.05$ were considered significant.

\section{Data Availability}

The datasets used to support this study will be made available upon reasonable request. Requests should be sent to the corresponding author.

\section{References}

1. Alani, A. et al. Balancing the risks and benefits associated with cosmetic dentistry - a joint statement by UK specialist dental societies. Br. Dent. J. 218, 543-548 (2015).

2. Aushill, T. M., Hellwig, E., Schmidale, S., Sculean, A. \& Arweiler, N. B. Efficacity, side effects and patients' acceptance of diferente bleaching techniques (OTC, in-office, at-home). Oper. Dent. 30, 156-163 (2005).

3. Mondelli, R. F. L., de Azevedo, J. F. D. G., Francisconi, A. C., de Almeida, C. M. \& Ishikiriama, S. K. Comparative clinical study of the effectiveness of different dental bleaching methods - two year follow-up. J. Appl. Oral Sci. 20, 435-443 (2012).

4. Bortolatto, J. F. et al. Low Concentration H2O2/TiO_N in Office Bleaching: A Randomized Clinical Trial. J. Dent. Res. 93, 66S-71S (2014).

5. Basting, R. T., Amaral, F. L., Franca, F. M. \& Flório, F. M. Clinical comparative study of the effectiveness of and tooth sensitivity to $10 \%$ and $20 \%$ carbamide peroxide home-use and $35 \%$ and $38 \%$ hydrogen peroxide in-office bleaching materials containing desensitizing agents. Oper. Dent. 37, 464-473 (2012).

6. Carey, C. M. Tooth whitening: what we now know. J. Evid. Based Dent. Pract. 14(Suppl), 70-66 (2014).

7. Briso, A. L. F. et al. Neurosensory analysis of tooth sensitivity during at-home dental bleaching: a randomized clinical trial. J. Appl. Oral Sci. 26, e20170284, https://doi.org/10.1590/1678-7757-2017-0284 (2018).

8. Rezende, M., Loguercio, A. D., Kossatz, S. \& Reis, A. Predictive factors on the efficacy and risk/intensity of tooth sensitivity of dental bleaching: A multi regression and logistic analysis. J. Dent. 45, 1-6 (2016).

9. Lucier, R. N. et al. Soft-tissue alterations following exposure to tooth-whitening agents. J. Periodontol. 84, 513-519 (2013).

10. Ribeiro, D. A., Marques, M. E. \& Salvadori, D. M. Study of DNA damage induced by dental bleaching agents in vitro. Braz. Oral Res. 20, 47-51 (2006).

11. Klaric, E. et al. Genotoxic effect of two bleaching agents on oral mucosa. Cancer Genomics Proteomics. 10, 209-215 (2013).

12. Costa, C. A., Riehl, H., Kina, J. F., Sacono, N. T. \& Hebling, J. Human pulp responses to in-office tooth bleaching. Oral Surg. Oral Med. Oral Pathol. Oral Radiol. Endod. 109, e59-64 (2010).

13. Cintra, L. T. et al. Penetration capacity, color alteration and biological response of two in-office bleaching protocols. Braz. Dent. J. 27, 169-175 (2016).

14. Coldebella, C. R. et al. Indirect cytotoxicity of a 35\% hydrogen peroxide bleaching gel on cultured odontoblast-like cells. Braz. Dent. J. 20, 267-274 (2009).

15. Dantas, C. M. G., Vivan, C. L., Ferreira, L. S., de Freitas, P. M. \& Marques, M. M. In vitro effect of low intensity laser on the cytotoxicity produced by substances released by bleaching gel. Braz. Oral Res. 24, 460-466 (2010).

16. de Almeida, L. C. et al. Color alteration, hydrogen peroxide diffusion, and cytotoxicity caused by in-office bleaching protocols. Clin. Oral Investig. 19, 673-680 (2015).

17. Ghalili, K. M., Khawaled, K., Rozen, D. \& Afsahi, V. Clinical study of the safety and effectiveness of a novel over-the-counter bleaching tray system. Clin. Cosmet. Investig. Dent. 6, 15-19 (2014).

18. Kirsten, G. A., Freire, A., de Lima, A. A., Ignácio, S. A. \& Souza, E. M. Effect of reservoirs on gingival inflammation after home dental bleaching. Quintessence Int. 40, 195-202 (2009).

19. Firat, E. et al. The effect of bleaching systems on the gingiva and the levels of IL-1 $\beta$ and IL-10 in gingival crevicular fluid. Oper. Dent. 36, 572-580 (2011).

20. Lima, S. N. L. et al. Evaluation of several clinical parameters after bleaching with hydrogen peroxide at different concentrations: A randomized clinical trial. J. Dent. 68, 91-97 (2018). 
21. Benetti, F. et al. Concentration-dependent effect of bleaching agents on the immunolabelling of interleukin-6, interleukin-17 and CD5-positive cells in the dental pulp. Int. Endod. J. 51, 789-799 (2018).

22. Martins, I. et al. Effectiveness of In-office Hydrogen Peroxide With Two Different Protocols: A Two-center Randomized Clinical Trial. Oper. Dent. 43, 353-361 (2018).

23. Maran, B. M., Burey, A., de Paris Matos, T., Loguercio, A. D. \& Reis, A. In-office dental bleaching with light vs. without light: A systematic review and meta-analysis. J. Dent. 70, 1-13 (2018).

24. Benetti, A. R., Valera, M. C., Mancini, M. N., Miranda, C. B. \& Balducci, I. In vitro penetration of bleaching agents into the pulp chamber. Int. Endod. J. 37, 120-124 (2004).

25. Kawamoto, K. \& Tsujimoto, Y. Effects of the hydroxyl radical and hydrogen peroxide on tooth bleaching. J. Endod. 30, 45-50 (2004).

26. Mena-Serrano, A. P. et al. Effects of the concentration and composition of in-office bleaching gels on hydrogen peroxide penetration into the pulp chamber. Oper. Dent. 40, E76-82 (2015).

27. de Oliveira Duque, C. C., Soares, D. G., Basso, F. G. \& Hebling, J. \& de Souza Costa, C.A. Influence of enamel/dentin thickness on the toxic and esthetic effects of experimental in-office bleaching protocols. Clin. Oral Investig. 21, 2509-2520 (2017).

28. Lee, D. H., Lim, B. S., Lee, Y. K. \& Yang, H. C. Effects of hydrogen peroxide (H2O2) on alkaline phosphatase activity and matrix mineralization of odontoblast and osteoblast cell lines. Cell Biol. Toxicol. 22, 39-46 (2006).

29. Borges, I. Jr. et al. Proinflammatory and oxidative stress markers in patients with periodontal disease. Mediators Inflamm. 2007, 45794, https://doi.org/10.1155/2007/45794 (2007).

30. Saeidnia, S. \& Abdollahi, M. Toxicological and pharmacological concerns on oxidative stress and related diseases. Toxicol. Appl. Pharmacol. 273, 442-455 (2013).

31. Kanzaki, H. et al. Pathways that Regulate ROS Scavenging Enzymes, and Their Role in Defense Against Tissue Destruction in Periodontitis. Front. Physiol. 8, 351, https://doi.org/10.3389/fphys.2017.00351 (2017).

32. Strzepa, A., Pritchard, K. A. \& Dittel, B. N. Myeloperoxidase: A new player in autoimmunity. Cell. Immunol. 317, 1-8 (2017).

33. Vaz, M. M. et al. Inflammatory response of human dental pulp to at-home and in-office tooth bleaching. J. Appl. Oral Sci. 24, 509-517 (2016).

34. Uitto, V. J., Overall, C. M. \& McCulloch, C. Proteolytic host cell enzymes in gingival crevice fluid. Periodontol. 2000. 31, 77-104 (2003).

35. Gomes, D. A. et al. Myeloperoxidase as inflammatory marker of periodontal disease: experimental study in rats. Immunol. Invest. 38, $117-122(2009)$.

36. Gupta, G. Gingival crevicular fluid as a periodontal diagnostic indicator- II: Inflammatory mediators, host-response modifiers and chair side diagnostic aids. J. Med. Life. 6, 7-13 (2013).

37. Khurshid, Z., Mali, M., Naseem, M., Najeeb, S. \& Zafar, M. S. Human Gingival Crevicular Fluids (GCF). Proteomics: An Overview. Dent. J. 5, E12, https://doi.org/10.3390/dj5010012 (2017).

38. Bruzell, E. M., Pallesen, U., Thoresen, N. R., Wallman, C. \& Dahl, J. E. Side effects of external tooth bleaching: a multi-centre practice-based prospective study. Br. Dent. J. 215, E17, https://doi.org/10.1038/sj.bdj.2013.1047 (2013)

39. Li, D. W., Li, J. H., Wang, Y. D. \& Li, G. R. Atorvastatin protects endothelial colony-forming cells against $\mathrm{H} 2 \mathrm{O} 2$-induced oxidative damage by regulating the expression of annexin A2. Mol. Med. Rep. 12, 7941-7948 (2015).

40. Fernandes, E. S. et al. TRPV1 deletion enhances local inflammation and accelerates the onset of systemic nflammatory response syndrome. J. Immunol. 188, 5741-5751 (2012).

41. Knowles, H., Li, Y. \& Perraud, A. L. The TRPM2 ion channel, an oxidative stress and metabolic sensor regulating innate immunity and inflammation. Immunol. Res. 55, 241-248 (2013).

42. Ogawa, N., Kurokawa, T. \& Mori, Y. Sensing of redox status by TRP channels. Cell Calcium. 60, 115-122 (2016).

43. Peus, D. et al. $\mathrm{H}_{2} \mathrm{O}_{2}$ is an important mediator of UVB-induced EGF-receptor phosphorylation in cultured keratinocytes. J. Invest. Dermatol. 110, 966-971 (1998).

44. Chen, D.L., Chen, T.W., Chien, C.T. \& Li, P.C. Intravenous low redox potential saline attenuates FeCl3-induced vascular dysfunction via downregulation of endothelial $\mathrm{H} 2 \mathrm{O} 2$, CX3CL1, intercellular adhesion molecule-1, and p53 expression. Transl. Res. 157, 306-319 (2011).

45. Förstermann, U. \& Sessa, W. C. Nitric oxide synthases: regulation and function. Eur. Heart. J. 33, 829-837 (2012),

46. Byers, M. R. \& Dong, W. K. Autoradiographic location of sensory nerve endings in dentin of monkey teeth. Anat. Rec. 205, 441-54 (1983).

47. Maeda, T., Iwanaga, T., Fujita, T., Takahashi, Y. \& Kobayashi, S. Distribution of nerve fibers immunoreactive to neurofilament protein in rat molars and periodontium. Cell. Tissue. Res. 249, 13-23 (1987).

48. Mendes, S. J. F. et al. Cinnamaldehyde modulates LPS-induced systemic inflammatory response syndrome through TRPA1dependent and independent mechanisms. Int. Immunopharmacol. 34, 60-70 (2016).

49. Bradley, P. P., Priebat, D. A., Christensen, R. D. \& Rothstein, G. Measurement of cutaneous inflammation: estimation of neutrophil content with an enzyme marker. J. Invest. Dermatol. 78, 206-209 (1982).

\section{Acknowledgements}

This work was supported by the Coordenação de Aperfeiçoamento de Pessoal de Nivel Superior (CAPES; grant number 3325/2013; finance code 001), Conselho Nacional de Desenvolvimento Científico e Tecnológico (CNPq; grant numbers 474999/2012-2 and 309046/2016-5), Fundação de Amparo à Pesquisa e Desenvolvimento Científico do Maranhão (FAPEMA; grant number UNIVERSAL- 01119/16) and Programa INCT-INOVAMED. N.C.F.S. is an undergraduate student and V.L.P.C. is an MSc student receiving studentships from FAPEMA. M.C.A. is an undergraduate student and D.M.S.P. and S.J.F.M. are PhD students receiving studentships from CAPES.

\section{Author Contributions}

V.L.P.C., S.N.L.L., N.C.F.S., M.C.A., D.M.S.P., S.J.F.M. and S.A.T. performed the experiments and drafted the manuscript; C.A.P., M.C.B., W.L.S., E.B.M., M.N.M. and E.S.F. designed the study; E.B.M. and E.S.F. performed the statistical analysis of the data; C.A.P., M.C.B., W.L.S., E.B.M., M.N.M. and E.S.F. drafted and critically revised the manuscript for important intellectual content. All authors reviewed and gave final approval to the final version of the manuscript.

\section{Additional Information}

Supplementary information accompanies this paper at https:/doi.org/10.1038/s41598-019-40006-w.

Competing Interests: The authors declare no competing interests. 
Publisher's note: Springer Nature remains neutral with regard to jurisdictional claims in published maps and institutional affiliations.

(c) (i) Open Access This article is licensed under a Creative Commons Attribution 4.0 International License, which permits use, sharing, adaptation, distribution and reproduction in any medium or format, as long as you give appropriate credit to the original author(s) and the source, provide a link to the Creative Commons license, and indicate if changes were made. The images or other third party material in this article are included in the article's Creative Commons license, unless indicated otherwise in a credit line to the material. If material is not included in the article's Creative Commons license and your intended use is not permitted by statutory regulation or exceeds the permitted use, you will need to obtain permission directly from the copyright holder. To view a copy of this license, visit http://creativecommons.org/licenses/by/4.0/.

(c) The Author(s) 2019 